\title{
Student-Athlete to Professional Athlete: Confronting the Brutal Facts
}

\begin{abstract}
By Angela S. Farmer*
When asked what they want to be when they grow up, children answer in a variety of ways. However, one promiant response focuses on becoming a superstar athlete. As age and competitive factors regularly remove this option from consideration for a majority of students, there are those for whom the dream maintains its promise into early adulthood. This study proposes to showcase the aspirational and institutional complexities that student-athletes experience as they attempt to rise from student-athlete to all-star professional while navigating the collegiate waters along the way. It is this unique paradox particularly crafted in the United States that is considered worthy of further exploration, discussion, and explanation in an attempt to offer educators a data-driven platform as they support student-athletes' in their journeys toward the pinnacle degree while maintaining the passion to dream the impossible dream.
\end{abstract}

Keywords: Matriculation Data, National College Athletic Association, Student-Athlete.

\section{Introduction}

Less than two percent of student-athletes ever play professional sports at any level for any duration (Goldman 2012) however, that does not resonate with many freshmen hopefuls across the nation who enter a university, singularly focused on the near impossible chance that they will have an opportunity to join the ranks of professional athletics.

Images of United States' superstars like Tom Brady, Peyton Manning, Dak Prescott, and LeBron James bring smiles to many young fans. Inspired by a magical potion with equal parts unparalleled talent, focus, determination and overall timing akin to winning the lottery, superstar athletes of this caliber inspire countless students to aspire to dream the impossible dream. While having role models and aspiring to follow in a successful star's footsteps can provide what appears to be a certain path toward greatness, the reality could not be further from the imagery.

Furthermore, as most paths toward the pros necessitate a stay in the collegiate arena, that environment, in and of itself, can many times prove to be quite overpowering, athletically, academically, and psychologically. One can certainly posit that the business of college sports, complete with its marketing, revenue streams, and passionate fan base has successfully taken over the initial image of the university setting as an intellectual aesthetic.

The data are clear; college athletics is big business. According to USA Today's 2016 report on the National College Athletic Administration's (NCAA) finances, the top school revenue was Texas A\&M, which boasted a school revenue

*Assistant Clinical Professor, Shackouls Honors College, Mississippi State University, USA. 
from the 2015-16 school year of $\$ 194,388,450$, an increase of $\$ 1,779,574$ from the previous year (USA Today 2016). Additionally, there are now 24 schools that make at least $\$ 100$ million from their athletic department, an increase of four schools from just one year ago and an increase of 13 institutions from the 2014 data (Gaines 2016).

Figure 1 presents the image of the revenues as well as the revenue disparities between programs. The graphical comparisons show Texas A\&M and the University of Texas, on the left of the bar chart, each of which, reportedly made in excess of $\$ 180$ million as compared to $44 \%$ of schools in Division I Athletics, on the far right of the chart, which made less than $\$ 20$ million per annum. This graphic underscores that even the smallest of these engaged schools are still realizing significant income (USA Today 2016), albeit an unarguably unbalanced sum when one's financial rewards and implications are in the hundreds of millions of dollars.

Figure 1. The Sports Chart of the Day

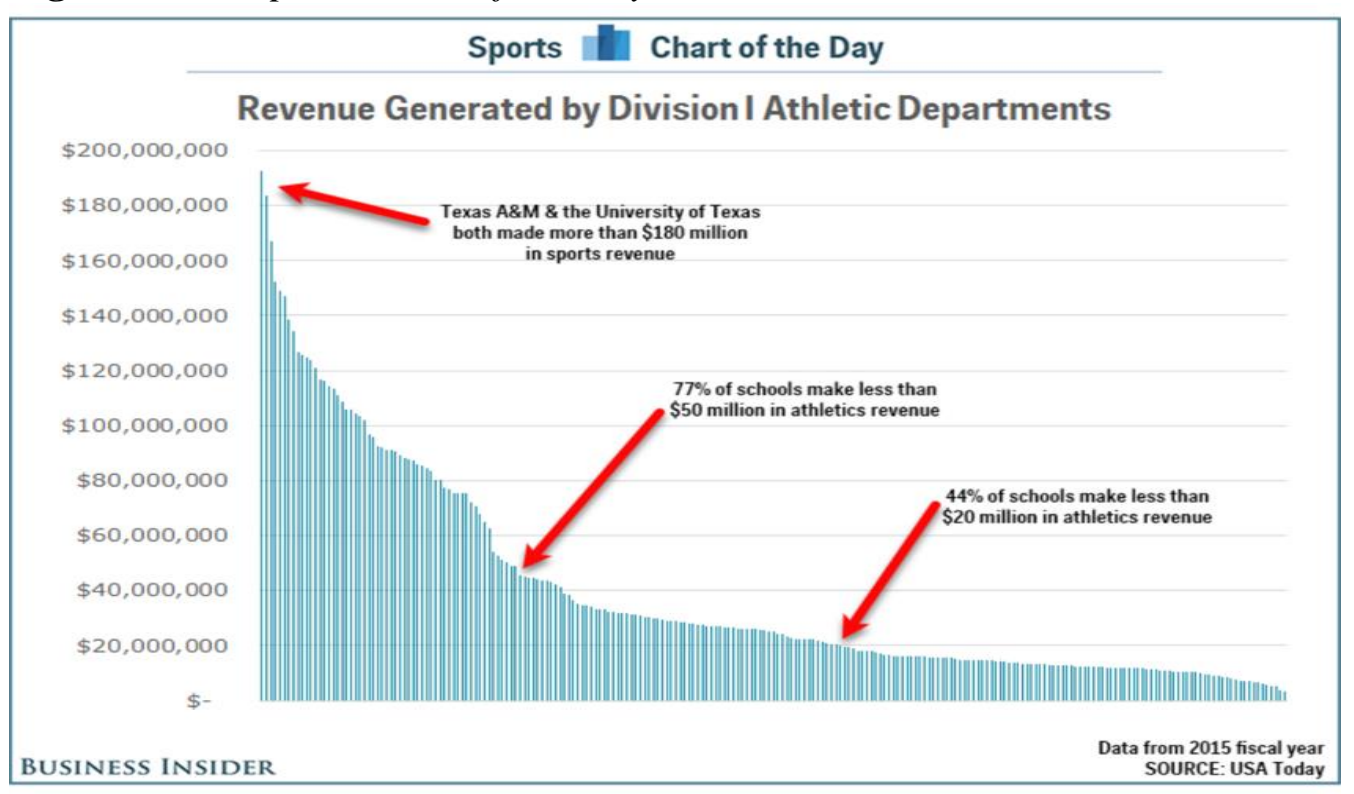

Source: USA Today (2016).

What is not disparate is the hopes and dreams of each college athlete on whom the revenues depend. Regardless as to whether the student emanates from a school in the Southeastern Conference (SEC) with an average revenue of $\$ 132.9$ million, the Sun Belt with an average revenue of $\$ 26.1$ million, or even the Ohio Valley Conference (OVC) with an average revenue of $\$ 13.5$ million (Kirk 2016), each individual, either based on reliable data or ideal optics, sees himself as levitating to professional level where finances are in full supply and fame and fortune are common commodities.

Furthermore, with the influx of revenue regarding athletics, the costs appropriated per individual athlete reinforce the fact that there is truly no reason for any athlete to be devoid of every advantage, particularly when one examines the financial appropriations per athlete versus the traditional student. 
Based on the National Collegiate Athletic Association's, independent analysis, there are eight significant conferences. The Knight Commission on Intercollegiate Athletics (Knight Commission 2019) reports the following dramatic financial figures. However, within these units there are five conferences, specifically, the Power Five known as the Atlantic Coast Conference, The Big Ten Conference, the Big 12 Conference, the Pacific 12 Conference, and the Southeastern Conference whose financial expanses dominate the landscape.

These Power Five not only spend, in some instances, many times what the other conference schools can afford per athlete, they also, in the case of the SEC, have their own television network which realizes huge financial gains for the conference, the universities involved, as well as an entourage of sponsors. It also celebrates the notoriety of the game and the particular athletes who play. According to the SEC's own tax records for 2017, distributions to their 14 member institutions averaged around $\$ 41$ million, with an upper range of $\$ 42.8$ million for the University of Georgia and lower ranges of \$39.9 million in some of the other schools within their conference (Berkowitz 2018).

While there is a dramatic variance between spending for student-athletes versus non-student-athletes in small-scale conferences like the American Athletic Conference which reports an acadmic spending of $\$ 15,711$ per fulltime traditional student versus $\$ 152,514$ per athlete, the differences pale when compared to Power Five Conference schools (Knight Commission 2019). For example, the Atlantic Coast Conference reports an academic spending of $\$ 18,369$ counter balanced with an allocation of $\$ 152,514$ per athlete. The Big 12 Conference continues the trend with an appropriation of $\$ 17,330$ per academic student against $\$ 186,518$ per athlete. The Big Ten evidences spending values of $\$ 21,056$ for academic students versus nearly $\$ 148,216$, that is nearly $\$ 150,000$, per individual student-athlete. Mirroring this spending gulf is the Pacific 12 Conference, reporting $\$ 17,888$ for traditional students against $\$ 153,351$ for student-athletes. Finally, the SEC, with its full docket of opportunites including the television network also affords academic spending appropriations of $\$ 15,821$ per student for traditional students versus $\$ 209,422$ per student for for student-athletes, over 10 times the allocation for non-student athletes.

Noteworthy in this data is the fact that athletic spending detailed provides an average, over all the university sports. When one analyzes spending on a per (United States) football athlete, an even larger disparity arises. For example, the SEC's athletic spending per football player is over $\$ 300,000$. When compared against smaller conferences such as Conference USA which appropriates $\$ 12,783$ for traditional academics against a less dramatic expanse of $\$ 74,429$ per studentathlete, it becomes easy to understand how the big business of collegiate sports has become an empire in select regions (Knight Commission 2019).

Furthermore, the larger, more successful conferences also realize the benefit of the enhanced resources as they provide for state-of-the-art facilites, exorbitant coaching salaries, and dramatically expanded student spending. All of these benefits are easy to provide in such settings where millions of dollars in revenue are also realized by the volumes of ticket sales and concession sales to literally hundreds of thousands of fans at each game. What may seem to 
further unbalance the scales for these mega-sports universities is the realization that their bottom line, budgetarily, is also relatively unimpacted by the need to supply additional institutional funding. These big conference athletic institutions can afford to cover their own expenses and still manage to gift additional monies to their universities. This empowers these mega-sport universities even further, as they do not need to access additional athletic spending allocations that are necessary in smaller school conferences, where athletics can be seen as a necessary aspect of the educational experience, versus the largest income generator in the entire geographic region.

\section{Literature Review}

Undoubtedly, collegiate student-athletes are poised in an institution where their designated objective is clearly focused on successful athletic outcomes. It is often a challenge for these students, who were selected based on their physical prowess not their academic merit, to maintain their status as a successful student. The pressures to also succeed as academic contributors in order to receive a college degree within their scholarship window, creates a dual-focused, seemingly oppositional goal set.

Attempting to reinforce academic focus on student-athletes', the NCAA's Academic Progress Rate (APR) was crafted to require academic institutions to spend additional time and resources toward ensuring student-athletes received increased academic support. However, while a 2010 study by Dr. Josh Castle demonstrated that " $66 \%$ of football programs increased resources to their academic budget" due to APR, many see this as window dressing (Castle 2010: 10). Accordingly, most universities utilize an array of learning specialists, academic advisors, and tutors to avoid embarrassment and to ensure that the most talented individuals remain eligible (Gurney and Southall 2012). Ironically, a research 2014 study performed by a collaboration of universities evidenced that the burden of ensuring compliance is placed heavily on the shoulders of academic support services personnel and not on the coaches or coaching staff (Kirkpatrict et al. 2014).

Given that "Complete College America" a nonprofit group out of Indianapolis, Indiana (Lewin 2014) reports that most traditional college students attending America's public colleges do not graduate on time, it is not surprising that this data also reflects the student-athletes. The article effectively articulates how the system of higher education in the United States is too expensive, too time consuming, and graduates too few to be effective. Furthermore, the report cites that only 50 out of over 580 public institutions graduate the majority of their students considered to be full-time within the four year timeframe, citing an almost limitless cafeteria of academic options paired with too few counselors to help students navigate the future options.

This article focuses on the prototypical, academic student who is not burdened by the excessive time expectations established by a collegiate sporting industry whose own rigor can cost student-athletes a time commitment 
similar to a full time job while they are expected to concomitantly, successfully manage a full academic workload (Lewin 2014). It only stands to reason that this daunting expectation can, at times, be found to create an overwhelming if not, impossible proposition. Given this set of stresses where students are under unfathomable pressure to perform, watched by millions of fans both in the stadium seats and from home settings on television networks, it is no surprise that the student-athlete's psychological balance can be impacted.

While the aspirations of greatness appeal to not only the most talented, but to those who also imagine themselves as the next big thing, the reality provides a much more discouraging picture. Only one in 16,000 high school athletes achieves a career as a professional athlete (Georgia Career Information Center 2006). In Figure 2 the probability of one realizing the aspiration to become a professional athlete within a variety of disciplines is provided (Kerr-Dineen 2016).

Figure 2. The Odds of Becoming a Professional Athlete

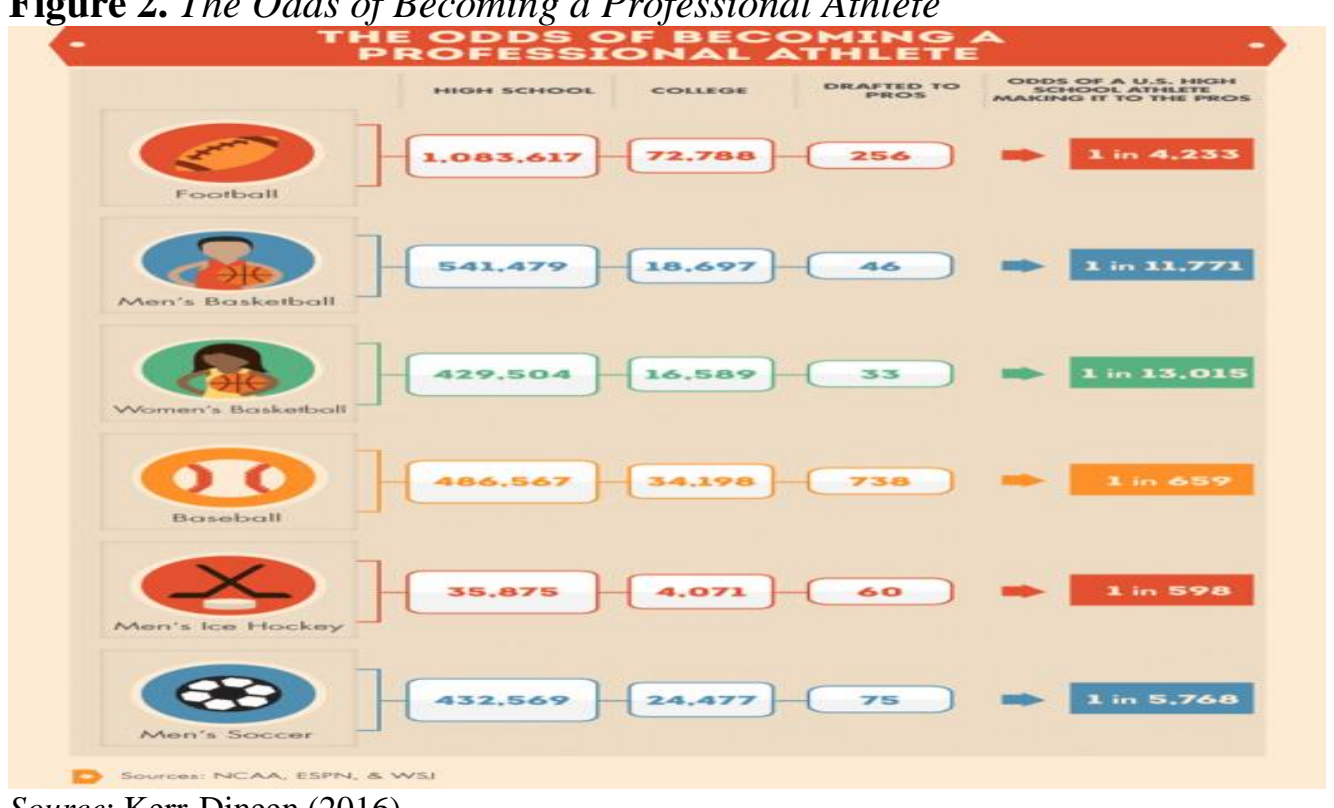

Source: Kerr-Dineen (2016).

As evidenced by this graphic, Men's Ice Hockey provides the most promising data; however, even then only one in 598 high school prospects can realize their dreams making it to the pros. The remaining sports of popularity in the United States all prove evidence of less than two percent matriculation from college to the pros, the only exception being baseball where a meager $2.1 \%$ have the chance to at least transition to a first year pro. This data provides grim evidence of the likelihood of those childhood dreams becoming an economic reality. Furthermore, once the fortunate few players find themselves in a professional league, most don't last longer than a single season. This underscores the reality of the temporary nature of both the game and its adjacent income continuity, which often terminates as abruptly as it initiated.

Clearly, the focus on the student-athlete often resonates as the athlete-student, where academic prowes assumes a minor role to the to the major draw of 
collegiate athletics. In an interview excerpt from Dr. Ruth Darling, academic athletic advising expert to those potential stars, she shares the following:

"I've worked with a number of student-athletes over the years who would say, "OK, I'm going to be a psychology major. But I'm really going to play pro or compete professionally. So it doesn't make any difference" (what I do or how I perform in school). I'll suggest, "Let's think about this a minute, about what this major will teach you about being that pro football player. You're going to learn about motivation, you're going to learn about persuasion, you're going to learn about figuring out how people think. All of these skills and the knowledge will help you out on the field. And whether you end up on the field or coaching or in the corporate world, you will take this knowledge, this degree with you." Often, their eyes light up. "Oh, I never thought about it that way!" I think helping students make this connection is one of the most important things we do. I keep trying to tie it back to what they have to do to be successful as an athlete and successful in life. You can't have someone lift your weights for you. You can't have someone else go in and memorize the playbook for you. You've got to go to class and fulfill your responsibilities as a student-athlete with integrity and pride. The bottom line is that connection: If you're not a student, you can't be a student-athlete. They must make progress on their degree. Sometimes, if anything, that is the hook" (Hamilton 2004: 1-2).

Some basic changes could facilitate the true utilization of the term "student" to provide at least a reasonable expectation for his attendance and academic outcome from the university. Some of those recommendations include an enhanced level of transparency to avoid instances like those exposed by The News \& Observer of Raleigh, North Carolina. The story found two, former student Tar Heels athletes turned pro, whose transcripts revealed a remarkably minimal amount of actual education during their tenure at the university. By pairing this transparency with enforcement of minimal GPA requirements (to play) and steering them into courses which would truly help them with life after college, the protocol could provide at least a minimal assurance of learning outcomes (Star-News 2012). Echoing the sentiment was NCAA President Myles Brand who warned against neglecting academic progress based on an assumption - whether by the student-athlete or the coach — that a professional athletics career is imminent.

"Only a handful of players go pro," he said. "The attrition we're seeing may be more because of an assumption on the part of players who desire to go pro that they in fact will make it and thus do not need to concentrate on academics. That is why we are holding institutions and coaches accountable for that academic progress, as a safeguard against such an assumption" (Brown 2005: 18). 
Regardless of the harsh realities of student-athletes actually matriculating into the professional realm, it is easy to understand how the data can become overshadowed by the tremendous financial influx accompanying collegiate sports. With a total reported revenue of $\$ 872.6$ million for the 2011-12 school year, clearly the NCAA's designation as a nonprofit entity is structured on how it uses the income and not on how much revenue is actually generated (Tracy and Rohan 2014). Further, the NCAA reports that in 2010-11 alone, the member schools spent nearly $\$ 12$ billion on athletics and created close to $\$ 6$ billion in revenue, which was primarily generated from football and basketball (The Economist 2013). Table 1 reveals the components of the revenue magnate for the 2011-12 school year.

Table 1. NCAA Revenue Breakdown

\begin{tabular}{|l|c|}
\hline NCAA revenue breakdown, 2011-12 & \\
\hline Television and Marketing rights fees & $81 \%$ \\
\hline Championships & $11 \%$ \\
\hline Investments & $4 \%$ \\
\hline NIT, LLC Eligibility Center, LLC College Football Arbiter eOfficials & $2 \%$ \\
\hline Contributions: facilities/other & $1 \%$ \\
\hline Sales and Services & $1 \%$ \\
\hline
\end{tabular}

Source: USA Today (2016).

With television and marketing rights fees amounting to over $80 \%$ of the entire income stream, it is abundantly clear that student-athletes have every reason to get confused along the way as to the emphasis area of their college experience.

Additionally, evidenced by Table 2, it is not surprising that Division I players especially feel the impact of the monumental fan base and the responsibilities that accompany the $63 \%$ of the expenses incurred by the NCAA on their behalf, especially when one notes that collectively, Division II (smaller schools) realize only four percent of that expense allocation.

Table 2. NCAA Expenses Breakdown

\begin{tabular}{|l|c|}
\hline NCAA expenses breakdown, 2011-12 & \\
\hline Distribution to Division I members & $63 \%$ \\
\hline Association-wide & $13 \%$ \\
\hline Division I championship and programs & $10 \%$ \\
\hline Division II distribution championships and programs & $4 \%$ \\
\hline General and Administrative & $4 \%$ \\
\hline Division III championships and programs & $3 \%$ \\
\hline Limited Liability Company & $3 \%$ \\
\hline
\end{tabular}

Source: USA Today (2016).

While professional sports like the National Football League (NFL) profess as the top tier for athletic prowess, the reality is that the NFL, even with its over \$10-billion-a-year enterprise, (Tracy and Rohan 2014) may soon find itself struggling to compete with collegiate predecessors. 
Furthermore, simply analyzing discrepancies between the college conferences lends a clearer view of the fiscal variances within the NCAA. Table 3 details the significant differences between these conferences. Most notable is the median athletic spending per athlete in the Southeastern Conference (SEC). While no student is directly receiving the full $\$ 163,931$ (Petchesky 2013) in salary, the expenses associated with training the outfitting and supporting the athlete and his image to sell the game amount to real dollars which provide a tangible segue to establish and nourish an ever expanding, almost manic fan base.

Table 3. Divisions and Allocations

\begin{tabular}{|l|c|c|c|}
\hline $\begin{array}{l}\text { Division I Subdivisions } \\
\text { and FBS Conferences }\end{array}$ & $\begin{array}{c}\text { Median } \\
\text { Academic } \\
\text { Spending per } \\
\text { Student, 2010 }\end{array}$ & $\begin{array}{c}\text { Median } \\
\text { Athletic } \\
\text { Spending per } \\
\text { Athlete, 2010 }\end{array}$ & $\begin{array}{c}\text { Ratio of Median } \\
\text { Athletic } \\
\text { Spending per Athlete } \\
\text { Academic Spending } \\
\text { per Student, 2010 }\end{array}$ \\
\hline Southeastern (SEC) & $\$ 13,390$ & $\$ 163,931$ & 12.2 \\
\hline Big 12 & $\$ 13,988$ & $\$ 131.286$ & 9.4 \\
\hline Pacific 10 & $\$ 14,217$ & $\$ 102,121$ & 7.2 \\
\hline FBS & $\$ 13,628$ & $\$ 91,936$ & 6.7 \\
\hline Atlantic Coast (ACC) & $\$ 15,360$ & $\$ 103,384$ & 6.7 \\
\hline Conference USA & $\$ 11,867$ & $\$ 76.181$ & 6.4 \\
\hline Big Ten & $\$ 19,225$ & $\$ 116,667$ & 6.1 \\
\hline Big East & $\$ 17.620$ & $\$ 102,032$ & 5.8 \\
\hline Mountain West & $\$ 13,690$ & $\$ 74,264$ & 5,4 \\
\hline Western Athletic (WAC) & $\$ 11,789$ & $\$ 56,180$ & 4.8 \\
\hline Sun Belt & $\$ 10,012$ & $\$ 41,796$ & 4.2 \\
\hline Mid-American & $\$ 13,069$ & $\$ 52,537$ & 4.0 \\
\hline Division I, No Football & $\$ 11,861$ & $\$ 39,200$ & 3.3 \\
\hline FCS & $\$ 11,769$ & $\$ 36,665$ & 3.1 \\
\hline Sourc: Petces & & & \\
\hline
\end{tabular}

Source: Petchesky (2013).

While the fiscal realities are but a factor in the overall equation of the effectiveness of college sports in matriculating student-athletes toward professional settings, they are nonetheless a significant factor. For example, the top athletic department money-makers for 2014-15 were Texas A\&M with a gross revenue of $\$ 192,608,876$; Texas at $\$ 186,521,028$; Ohio State at $\$ 167,166,065$; Michigan at $\$ 152,477,027$; Alabama at $\$ 148,911,674$; Florida at $\$ 147,105,252$; Louisiana State University at $\$ 138,642,237$; Oklahoma at $\$ 134,269,349$; Tennessee at $\$ 126,584,033$; and Penn State at $\$ 125,720,619$ (Lavigne, 2016). With athletic gross revenues nearing billions of dollars in instituions which were created under the auspice of educating students, it is not difficult to see how vulnerable student-athletes can become confused as to the institution's mission and their role within the empire.

Table 4 evidences high school baseball hopefuls have only a one-half of one percent chance of going pro, for one year. The best college to pro athletes' matriculation rates are provided by men's ice hockey (for schools who even 
offer such venues) at $12.9 \%$. For football and basketball, the numbers are dramatically more dismal.

There is only hundredths of a percent chance for a student to go pro from high school, and only one to two percent chance that he makes it big going from college to the pros. A study generated by the NCAA (NCAA nd) concluded:

"Sadly though, it comes as a rude surprise to many athletes yearning for a professional sports career to learn that the odds against success are astronomically high. Approximately one percent of NCAA men's basketball players and two percent of NCAA football players are drafted by NBA or NFL teams - and just being drafted is no assurance of a successful professional career. "Student-athletes" whose sole and now failed objective was to make the pros suddenly find themselves in a world that demands skills their universities did not require them to learn."

Table 4. Athletic Realities (Georgia Career Information Center 2006)

\begin{tabular}{|l|c|c|c|c|c|c|}
\hline $\begin{array}{l}\text { Student } \\
\text { Athletes }\end{array}$ & $\begin{array}{c}\text { Men's } \\
\text { Basketball }\end{array}$ & $\begin{array}{c}\text { Women's } \\
\text { Basketball }\end{array}$ & Football & Baseball & $\begin{array}{c}\text { Men's Ice } \\
\text { Hockey }\end{array}$ & $\begin{array}{c}\text { Men's } \\
\text { Soccer }\end{array}$ \\
\hline $\begin{array}{l}\% \text { High } \\
\text { School to } \\
\text { College }\end{array}$ & $2.9 \%$ & $3.1 \%$ & $5.8 \%$ & $5.6 \%$ & $12.9 \%$ & $5.7 \%$ \\
\hline $\begin{array}{l}\% \text { College } \\
\text { to Pro }\end{array}$ & $1.3 \%$ & $1.0 \%$ & $2.0 \%$ & $10.5 \%$ & $4.1 \%$ & $1.9 \%$ \\
\hline $\begin{array}{l}\% \text { High } \\
\text { School to } \\
\text { Pro }\end{array}$ & $0.03 \%$ & $0.02 \%$ & $0.09 \%$ & $0.5 \%$ & $0.4 \%$ & $0.08 \%$ \\
\hline
\end{tabular}

Source: National Collegiate Athletic Association. Estimated Probability of Competing in Athletics Beyond the High School Interscholastic Level.

\section{Methodology}

The impetus for this study was motivated by three years of qualitative, observational research with student-athletes at a large, land-grant university in the Southeastern Conference in the United States. Each summer for three years, from 2015 through 2017, the researcher worked with the 105 male, studentathletes who were scholarshiped through the university to play collegiate football the following fall. The researcher was invited by the head football coach, at that time, to work with his players in an effort maximize their leadership abilities and improve their team synergy with each other as well as with their individual coaches. The data that emanated from these three years of research was evidenced through an observational lens as she worked to improve the team dynamic by enhancing the students' understanding of themselves. Therefore, although the data points are broad with over 105 student-athletes each of three years, the research should be considered as qualitative as it was observational in nature and was gathered as the researcher working to help solve a larger problem of team efficacy which, according to the coach that 
requested the intervention, was seen as a limiting factor which kept the team from achieving maximal athletic outcomes.

During her work these three summers (2015-2017), the researcher began to recognize some particular behaviors and student stresses which warranted her request for Institutional Review Board approval to work with the students' data in order to target answers to key questions. The key questions were as follows:

- "How does a student-athlete's focus on post-collegiate or professional aspirations impact his aspirations toward attaining a college degree?

- "What particular types of personalities are linked to the greatest stress in trying to accommodate an active student-athlete profile and concomitant aspiration for professional success?"

The researcher, a certified Myers-Briggs trainer, utilized the Myers-Briggs Type Inventory (MBTI), paper Form M, to facilitate the students' utilization of said inventory. For clarity, Myers-Briggs training requires practitioners to go through a rigorous training developed by $\mathrm{CPP}$, Inc. to ensure consistency and reliability of instructors and trainers to help participants determine their natural type tendencies and to help translate the findings of the individual inventories.

Participants were invited to take a MBTI assessment which asked participants to answer a series of 93 questions to determine their personality preferences. Outcomes indicated to the researcher, not the subjects' limitations, but rather their preferences in a given set of circumstances and settings, allowing her to determine strengths and areas for growth within that native personality. As the researcher recognized that there were challenges with some of the students' comprehension of select terms, she covered each question individually to ensure that the student-athletes fully understood the question asked and the choices offered in order to maximize the chance that the student-athletes' responses were accurate.

Following the recovery of each student-athlete's MBTI type, the researcher met with groups of similar (personality) types to understand the challenges that their select type faced when trying to navigate the complex responsibilities of playing football in the Southeastern Conference, a highly selective and most competitive environment.

The researcher spent multiple, extended hour-long sessions with groups of student-athletes. Depending upon student access, she also spent thirty to sixty minute sessions with each of the individual student-athletes to better understand their stresses as they related to the academic-athletic dichotomy. Furthermore, she also typed all 25 coaching staff members each year to better appreciate how their interactions with the students could be adjusted to maximize the relationship efficacy.

The researcher's notes were coded based on MBTI preferences and limited to the group and individual player's stresses surrounding the dream of making to the pros and how the university experience impacted that dynamic. Furthermore, the notes were taken by hand and aggregated by group type, careful not to identify any individual student-athlete whose vulnerability could expose 
him to negative consequences within his athletic realm. The researcher gained Institution Review Board permission to use the information to publish the findings only after assurances were given that no student data would be shared, distributed, or identifiable.

The subjects were asked the following questions in groups established according to similarity in type.

Questions:

1. Does your indicated personality type align with your view of yourself?

2. Does your type impact how you operate with others on your team?

3. Do you recognize that most players will not go pro?

The physical setting used was a personal office within the large, football complex of coaching offices designated for football athletics and personnel. The data was maintained in a locked file cabinet in a desk drawer of said office which was also kept under locked seal. The interviews were conducted for individuals within this office space. The larger, group meetings were held in the football meeting room, a 200 seat theater venue also within the football complex. At no time during the meeting were coaching staff allowed to interrupt the meetings, in order to ensure both confidentiality as well as student comfort within the work sessions with the researcher.

The researcher's role was observational with regard to their type selections and presented ways in which select types could improve their interactions based on type tendencies. Questions posed were given in a manner which allowed participants to answer in a frank and conversational manner or not to answer, as was their prerogative. Answers to the questions helped the researcher better understand the stresses that select types experienced as well as provided an indication as to why their focus on academic merit may have been less than a primary concern.

\section{Findings}

Regardless as to the likelihood of matriculating from a scholastic setting to the professional field, students along the three-year interval nearly all considered their placement on the college team as a seque toward the pros. Exceptions were walk-ons whose selection to the collegiate team was tenous. The athletes met the initial conversation where they faced the minimal and harsh facts that their transition to the professional arena was more than unlikely, with disagreement, denial, and even with some hostility.

Discussing how individuals could maximize their academic and organizational strengths while minimizing their propensity for conflict was a powerful and time-consuming souce of dialog. Given the expanse of poverty within the group, their passion to escape the confines of their limited financial means, many studentathletes saw their aspirations of making large salaries at the professional level as an all-or-none option. 
Few recognized the reality or the benefit that they were afforded in receiving scholastic consideration other than viewing it as a first step. Notable time and consideration were given to select student who presented with the most intense stresses. For example, students who themselves had childen were of particular concern.

There were notable findings, however, within the students tested. The student-athletes whose type inventory revealed them to carry or demonstrate a stronger affiliation toward feeling versus thinking, one of the MBTI dichotomies, appeared particularly susceptible to focusing strictly on the dream of going to the professional leagues, and were notably more indifferent toward their roles as student-athletes focused on securing a college degree.

Specifically, the individuals whose preference toward Feeling vs. Thinking were intensely focused on the prize of a professional contract and noticeably more indifferent to their roles as student-athletes intent on getting the college degree. While they offered little explanation as to why they would not focus on the opportunity at hand, their passion for fame and family security viewed as only available through a pro contract dominated their perceptions and dreams.

Those groups who were more focused toward Thinking, while also susceptible to dreams of stardom, were typically more pragmatic and willing to discuss secondary plans if they did not make it to the pros. However, their efforts and academic data were not notably superior to the student-athletes with Feeling preferences over Thinking preferences.

Interestingly, the teams progressively, from 2015 to 2017 began to increase in their preference for Feeling versus Thinking in the T/F dichotomy used in MBTI analysis. Whether this was significant was not known; however, it is worth noting that the coaching/recruiting staff became increasingly sensitive to the concept of type and trying to bring divergence of thought and strategy to the recruiting classes after they inititated the training with the researcher in 2015. This may have contributed to the more balanced evidence of type between Thinking and Feeling types after 2015. In one instance, the head coach requested the researcher organize the student-athletes positioning in the locker room to maximize team efficacy based on type. Beginning in 2015, the majority of players showed a preference toward Thinking; however, by 2017, there was an almost even split between Thinking and Feeling preferences. While this evidenced a more balanced team dynamic, the increase in Feeling preference generated an increased perception among the players, tipping the overall synergy of focus toward the goal of going pro. Discussions of the benefits of collegiate, academic success became more challenging for the researcher. Furthermore, given that one, stellar team member was, in fact, recruited for a professional team during this time did little to abet the manic passion to follow his lead, as if it were simply a personal preference, independent of talent and timing.

Many of the coaching staff interviewed along the timeline recognized the reality that these students focused little direction toward athletic efficacy, but few saw it as a challenge to their coaching practices, an evidentiary finding consistent with findings from previous researchers (Kirkpatrick et al. 2014). 
Most of the interviewed coaches, rather, recognized the dream but saw their mission to coach for the moment rather than to mentor for the future. Two, individual, coaches were especially noteworthy as they had personal experiences attesting to both realizing the professional aspiration as well as experiencing the challenges faced.

This rather intense dynamic where student-athletes face tremendous pressures by their families as well as their coaches and even their teaches to be successful, places an extraordinary burden upon young adults. The studentathletes' lack of awareness of the realities of professional, athletic success was powerful in its impression on the researcher who aspired to understand how the student-athetes could find themselves in a scenario whereby temporary athletic prowess could be the determining factor in the success or failure of their entire future.

\section{Discussion}

Given that student-athletes aspiring to become professionals face such abysmally low rates of matriculation to the professional landscape, it is interesting to learn that while they are giving it their all, their coaches are already, in many cases, realizing the gold at the end of the rainbow. With collegiate coaching salaries for the 2014-15 fical year reported to be in excess of \$28 million at Ohio Sate, over \$25 million at Kentucky, and over \$24 million for the flagship universities in Alabama, Michigan, and Florida (Lavigne 2016), it is not surprising that the focus is on the team and the players' composite impact, not on ensuring that each realizes a college degree while being mentored toward the pros.

While college athletes struggle to survive even with the new allocations trickling through the NCAA to member institutions, according to "Visualizing the Yearly Salary of Professional Athletes," National Basketball Association (NBA) Players Average \$5+ Million a Year, the NBA's average player receives $\$ 5.15$ million per year, surpassing Major League Baseball by $\$ 1.85$ million (Huffington Post 2014). While the 2017-18 NBA Player Contracts show annual compensation packages ranging from $\$ 35.6$ million for Stephen Curry and $\$ 33.2$ million for LeBron James down to the indiscriminate wages of Demetrius Jackson and Georges Niang, which hover around the $\$ 100,000$ mark, the average salary stands at over $\$ 6.3$ million dollars (basketball-reference.com n.d.). Clearly, the motivation to join the team becomes most transparent once one can see the wealth associated with those most fortunate few. Even with the lowest compensated players in the NBA, their salary status belies the average household income in the United States of $\$ 56,718$ (US Census Bureau 2016) by nearly two-fold.

Comparatively, there is little one can do to disavow the disparate compensations between some of America's favorite sporting organizations. On average, in comparison to the NBA's average player compensation of $\$ 5.15$ million, the statistics drop measurably with Major League Baseball Players 
making \$3.2 million, National Hockey League players reporting \$2.4 million, all followed by National Football League players who average a mere $\$ 1.9$ million per year (Manfred 2013).

While the student-athletes interviewed were consistent in their passion for their future, few recognized that the passion also should be mirrored in their academic journey. Many of the student-athletes presented with minimal reading fluency when given the Myers-Briggs Type Inventory, requiring the researcher to define the terms in advance of future discussions. The terms in question were within an eighth grade reading vocabulary. There was a noticeable difference between one dichotomy of players as those with Feeling preferences were least likely to focus on anything other than going pro. Thinking preferences were less opposed to recognizing the reality; however, their academic efforts were not elevated beyond the other groups. Furthermore, the players often presented as incredulous when told that most of them would not be going to the National Football League and that they needed a back-up strategy.

According to former Detroit Lions wide receiver, Ryan Broyles, "You're not going to be able to play this game forever - So how are you going to hold on and how are you going to be a good steward of your money?" (Green 2015: 1). For student-athletes who do not complete their college degree, rather they run out of eligibility and have insufficient funds to finish or declare for the pros, in football, and are not drafted, the end game is the same. Ultimately, these kids, the true moniker for student-athletes, need to be supported by adults who understand that each individual needs to advocate for his academic pursuits, regardless as to his potential for the pros. Even some of the very best athletes, never make a long career in a professional league.

Acquiring a degree, on the other hand, provides a pinnacle artifact that never expires. Much like an omnipresent umbrella, a degree provides enhanced financial security for a rainy day. Given the unpredictable nature of professional sports, the plethora of talents against which players must prevail on a daily basis, and the ever clear and present danger of an injury, having the insurance policy a degree affords, endows even the most gifted, with a valid backup plan. This removes some of the stress of having to depend exclusively on athletic ability for their future financial security.

While this transformation from student-athlete to professional may sound ideal, one notable who made the journey rejected the option for his own children. Ironically, mega-athlete LeBron James was criticized in 2014 for not allowing his sons to play football. His responded, "I needed a way out (of poverty). My kids don't" (Zirm 2015). It is this evidenced-based realization which fully underscores the justification for a significant number of student-athletes' fantasy.

It has never been more transparent that the distinction between what's best for the individual student-athlete and what's best for the mega sports university, may not always be the same thing. In "Rich get richer in college sports as poorer schools struggle to keep up" ESPN's Paula Lavigne (2016) notes that the Power Five conferences realized a record of $\$ 6$ billion in 2015, nearly $\$ 4$ billion more than all other schools together (Lavigne 2016: 1), attesting to the 
fact that the college sports' haves and have-nots is at an all time high (Lavigne 2016).

It is entertaining for children to envision themselves as any variety of exceptional, adult versions of themselves as professional athletes. Unfortunately, however, the realities of such aspirations are rarely communicated with the efficacy necessary to ensure that student-athletes recognize the necessity and associated background knowledge paramount to focus on the student facet in their roles as student-athletes.

Many aspiring student-athletes in elementary and high schools across the nation are drawn to the glow of Friday night lights from their school, court, or field. While a select set may find themselves matriculating to the collegiate arena, it is the NCAA's own advertising which touts that "there are more than 380,000 student-athletes and most of them will go pro in something other than sports" (Wong et al. 2011: 1). This reality is often hard to process amid the intensely marketed programs of the NCAA as well as the professional sporting programs. Furthermore, with the tremendous financial allocations devoted to the world of collegiate athletics, it is easy to understand how student-athletes can become distracted by the financial ependitures and promises of fame and fortune. When student-athletes witness an institutional setting like athletic superpower, the University of Alabama spending over $\$ 200,000$ per studentathlete versus an average spending of less than $\$ 20,000$ for its traditional academic students, it is not difficult to understand how such athletes could begin to imagine their treck to the professional landscape as a given commodity (Lavigne 2016).

Furthermore, when Academic Progress Rates are included into the dynamic, it becomes clear that institutions which boast wealthier athletic revenues are more able to adapt to these demands; however, even in these settings, the research indicated that it had not impacted the type of collegiate athelete recruited, specifically when it related to revenue generating sports like football (Kirkpatrick et al. 2014).

One exceptionality that was evidenced by this research was the difficulty that many players faced in addressing their academic challenges, independent of their athletic talent threshold. For this research effort, conducted over three summer sessions with male, United States football player, student-athletes within a landgrant university in the Southeastern Confernce, significant apathy was recognized when the students were faced with the knowledge that most would not make it to the pros. Those players whose type relied more one Feeling than Thinking were especially intent on a singular focus on becoming a star and viewed collegiate athletics as a necessary stop on the path.

Unfortunately, for those who would accept that an education was, in fact, an essential component of their aspirational journey toward stardome, many lacked the necessary academic background to make that goal a reality within the timeline allowed for their eligibility. This awareness further reinforced that many of the student-athletes observed were essential to the organization's winning team strategy but lacking the necessary academic skillset to successfully achieve a college degree. 


\section{Conclusions}

The data belies the truth, in that only the fortunate few make it to the pros, and even that is most often a short tenure. Long term NFL veteran, Terrell Buckley shares some honest insight. He is one of the fortunate few whose academic merit and athletic talents afforded him the most outstanding of opportunities to actually realize the dream of being a high school super-star, an exceptional college player and graduate, as well as a drafted NFL athlete who no only played but stayed in the league for years, going on to a Super Bowl Championship in the Super Bowl XXXVI, with the New England Patriots (Mask 2002). Giving back to his community, Buckley serves a valuable role as he returned to the SEC to coach and mentor athletes to be the best they can be, all the while reinforcing their need to get a degree. He provided valuable insight as he shared this reality attesting to the fact that "only three percent" of even those who make it pro (in the NFL) last past that first year (Buckley 2017).

The reality comes down to simple math. While scores of parents dream of their child cashing in on an athletic scholarship, there are some harsh facts associated with winning such prizes. The fine print in even the brightest of these opportunities, always affords the institution the option as to whether he becomes an actively engaged player.

Unfortunately, only about two percent of high school athletes win sports scholarships every year at NCAA colleges and universities, of those, the average scholarship is less than $\$ 11,000$, significantly below the illustrious lure of full-ride scholarships of dreams (O'Shaughnessy 2012). Furthermore, those who play for a scholarship received still must work diligently both on and off the field or court of play. An NCAA survey revealed that playing football required 43.3 hours per week; college baseball, 42.1 hours; men's basketball, 39.2 hours; and women's basketball, 37.6 hours (O'Shaughnessy 2011). These time commitments are independent of the hours necessary to attend class, complete assignments, and study for exams.

Ultimately, one must realize that a career in professional sports is more than a lofty goal, much like the odds of winning the lottery, it is more of a mirage than an oasis for the greatest majority of student-athletes. This research with a United States, collegiate football program in a landgrant university in the Southeastern Conference, reinforced the widely held beliefs that studentathletes aspire toward the goal of becoming professional athletes, often ignoring the more attainable academic experience opportunity provided along the route.

Using a widely used personality type tool, the MBTI, the researcher was able to qualitatively support the athletes' overarching motivation and focus, providing an enhanced lens, evidencing that those with a preference for Feeling were especially vulnerable to ignoring their present situation and need for an academic focus as they were more likely than those with a Thinking preference to see the dream of tomorrow's stardom potential and ignore the gift of today's collegiate opportunity.

Clearly, the best bet for student-athletes to realize their full potential is to concentrate on supporting their athletic prowess with an academic defense 
strategy that allows for a sustained synergy, producing true student-athletes who know the reality of professional sports so that they can continue to dream the impossible dream. Consistently planning for both the immediate and the more distant future ensures that these athletes maximize not only the short game of play today but the long game where both academic gains and athletic gifts combine to produce student-athletes who evolve into lifelong learners. Perhaps best captured by veteran NFL player, Chris Boniol, whose career spanned history as a former college star turned NFL kicker and even Superbowl MVP for the Dallas Cowboy's Super Bowl XXX win (Bayless 1999). Boniol, now a kicking coach for the NFL's Tampa Bay Buckaneers, explained how kids are "driven by the dream and when the dream is no longer a reality, the drive no longer exists. There has to be a plan," says Boniol. "A plan for the pros and a plan for life independent of the pros. That's what students need if they are going to truly succeed in the game" (Boniol 2019).

\section{References}

Basketball-Reference (nd) 2017-18 NBA Player Contracts. Retrieved from https://www. basketball-reference.com/contracts/players.html. [Accessed 15 September 2017].

Bayless S (1999) Boniol could kick himselffor bad decisions. Chicago Tribune. Retrieved from: https://www.chicagotribune.com/news/ct-xpm-1999-10-16-9910160185-story. html. [Accessed 15 September 2017].

Berkowitz S (2018) SEC paid an average of about \$41 million to each school in 2017. USA Today. Retrieved from https://bit.ly/2rYhQLf. [Accessed January 2019].

Boniol C (2019). Advice for student-athletes. (A. Farmer, Interviewer).

Brown GT (2005) Going pro doesn't necessarily translate into APR going south. NCAA News 42(6): 18.

Buckley DT (2017) Mississippi State University Coach. Personal Conversation. (A. Farmer, Interviewer) Mississippi State, MS, USA.

Castle $\mathrm{J}$ (2010) The impact of academic progress rating on the retention and recruiting strategies of NCAA division I football programs. Unpublished manuscript.

Gaines C (2016) The 25 schools that make the most in college sports Retrieved from https://read.bi/2p5fllK. [Accessed 15 September 2017].

Georgia Career Information Center (2006) From high school to pro - who will go? Retrieved from https://whenyoucantgopro.weebly.com/uploads. [Accessed July 2018].

Georgia Career Information Center (2006) Dreaming of becoming a college or professional athlete? From high school to pro - how many will go? Georgia, USA: www.gcic.pe achnet.edu.

Goldman J (2012) Sports and Society: Can Sports Be an Effective Path out of Poverty for Youth? Retrieved from www.bleacherreport.com. [Accessed 7 September 2017].

Green R (2015) Former Oklahoma Sooner star Ryan Broyles pushes financial literacy. Retrieved from https://bit.ly/2NWC5Up. [Accessed 7 September 2018].

Gurney G, Southhall R (2012) College Sports Programs Bait and Switch. Retrieved from https://es.pn/2Y2Y6EV. [Accessed March 18 2019].

Hamilton K (2004) Creating a successful student-athlete: discipline, focus and hard work are just a few attributes, says advising expert Dr. Ruth Darling. Black Issues in Higher Education 21(4): 30. 
Huffington Post (2014) Visualizing the Yearly Salary of Professional Athletes, NBA Players Average \$5+ Million a Year. Retrieved from https://bit.ly/2zIhjjP. [Accessed 15 September 2017].

Kerr-Dineen L (2016) Here are your odds of becoming a professional athlete. Retrieved from https://bit.ly/2GwtmTJ. [Accessed July 2018].

Kirk J (2016, July 6) SEC schools averaged \$130M in revenue, and more. Retrieved from www.sbnation.com/2017/7/6/15930008/college-sports-revenue-athletic-departmentmoney-rankings-2017 [Accessed 15 September 2017].

Kirkpatrick N, Hawkins B, Hill J, Maxcy J (2014) The impact of the academic progress rate (APR) on low resource or non-BCS institutions as it relates to football and/or men's basketball programs. Journal of Issues in Intercollegiate Atletics 7: 263-284.

Knight Commission (2019) Improve the accountability for spending in college athletics. Retrieved from https://bit.ly/181WPo8. [Accessed December 2018]

Lavigne P (2016) Rich get richer in college sports as poorer schools struggle to keep up. Retrieved from https://es.pn/2bQngek. [Accessed February 2019].

Lewin T (2014). Most college studens don't earna degree in 4 years, study finds. Retrieved from https://nyti.ms/2oWlq5b. [Accessed February 2019].

Manfred T (2013) Two Charts that Expose How Badly NFL Players Get Paid. Retrieved from businessinsider.com. [Accessed 15 September 2017].

Mask M (2002) Patriots win on field goal on final play of Super Bowl. The Washington Post. Retrieved from: https://wapo.st/2SiwXIQ. [Accessed 14 September 2017].

NCAA (nd) NCAA.org. Retrieved from http://www.ncaa.org. [Accessed 19 September 2017].

NCAA (nd) Pathway to lifelong success. Retrieved from http://www.ncaa.org/opportu nity/ [Accessed February 2019].

O'Shaughnessy (2011) Do College Athletes Have to Be Students? Moneywatch. Retrieved from https://www.cbsnews.com. [Accessed November 2018].

O'Shaughnessy (2012) 8 things you should know about sports scholarships. Retrieved from https://www.cbsnews.com. [Accessed November 2018].

Petchesky B (2013) SEC Schools Spend \$163,931 Per Athlete, And Other Ways The NCAA Is A Bonfire For Your Money. Retrieved from https://bit.ly/2GuCWqa. [Accessed 19 September 2017].

Star-News (2012, August 21) All schools must take action to make student athletes accountable. Wilmington, NC, USA.

The Economist (2013) Fair or foul? Unpaid student athletes are at the heart of a multibillion-dollar industry. Retrieved from https://econ.st/2YUuUNJ [Accessed 19 September 2017].

Tracy M, Rohan T (2014) What Made College Football More Like the Pros? \$7.3 Billion, for a Start. Retrieved from https://nyti.ms/1zuOjA1. [Accessed 19 September 2017].

US Census Bureau (2016) Retrieved from https://www.thebalance.com/what-is-averageincome-in-usa-family-household. [Accessed 15 September 2017].

USA Today (2016) NCAA Finances. 2015-16 FINANCES. Retrieved from sports.usa today.com. [Accessed 15 September 2017].

Wong GM, Zola W, Deubert C (2011) Going Pro in Sports: Providing Suidance to Student-Athletes in a Complicated Legal \& Regulatory Environment. Cardozo Arts \& Engertainment Law Journal 28: 553.

www.npr.org/templates/story/story.php?storyld=4757704 (Producer) (2005) A Mind is A Terrible Thing to Waste [Motion Picture].

Zirm J (2015) LeBron James Has an interesting answer as to why he won't let his sons play football. Retrieved from https://www.complex.com/sports/2015/11/lebron-ja mes-why-he-wont-let-sons-play-football [Accessed 1 January 2019]. 